\title{
Proses Berpikir Kreatif Matematis Siswa Extrovert dan Introvert SMP Kelas VIII Berdasarkan Tahapan Wallas
}

\author{
Nanda S. Pangestu1 ${ }^{*}$ dan Tri N. H. Yunianta ${ }^{2}$ \\ 1,2Program Studi Pendidikan Matematika, Universitas Kristen Satya Wacana \\ Jalan Diponegoro No. 52-60, Salatiga, Jawa Tengah, Indonesia \\ 1*202015024@student.uksw.edu,2trinova.yunianta@staff.uksw.edu
}

Artikel diterima: 29-03-2019, direvisi: 26-05-2019, diterbitkan: 31-05-2019

\begin{abstract}
Abstrak
Kemampuan berpikir kreatif penting bagi siswa dalam menyelesaikan masalah matematika dengan variasi cara. Mengenal kepribadian siswa juga berguna untuk memahami motivasi siswa. Tujuan penelitian kualitatif deskriptif ini mendeskripsikan proses berpikir kreatif siswa dengan tipe kepribadian extrovert dan introvert berdasarkan tahapan Wallas. Subjek penelitian yaitu 2 siswa introvert dan 2 siswa extrovert kelas VIII SMP Negeri 3 Salatiga berkemampuan matematika tinggi. Instrumen utama adalah peneliti. Instrumen bantu berupa soal tes, pedoman wawancara, dan dokumentasi. Hasil penelitian menunjukan pada tahap persiapan subjek extrovert lebih percaya diri bertanya kepada teman mengenai hal yang kurang dipahami, membaca soal dalam hati, sedangkan subjek extrovert selalu bertanya kepada peneliti dan membaca soal dengan bersuara. Pada tahap inkubasi subjek introvert tidak banyak melakukan aktifitas fisik hanya beristihat sejenak dengan merenung dan berdiam diri sedangkan subjek extrovert mununjukkan aktifitas fisik. Tahapan iluminasi subjek introvert dan exstrovert sama-sama mengembangkan ide dengan cara sebelumnya. Pada tahap verifikasi subjek introvert lebih teliti dibanding subjek extrovert namun sama-sama memiliki variasi cara. Secara umum siswa dengan tipe kepribadian extrovert dan introvert telah memenuhi seluruh tahap proses berpikir kreatif Wallas. Kata Kunci: Extrovert, Introvert, Proses Berpikir Kreatif, Tahapan Wallas.

\section{Mathematical Creativity Thinking Process of Extrovert and Introvert Student at SMP Class VIII Based on Wallas Stages}

Abstract

The ability to think creatively is important for students in solving mathematical problems in various ways. Getting to know students' personalities is also useful for understanding student motivation. The purpose of this descriptive qualitative study describes the creative thinking process of students with extrovert and introverted personality types based on the stages of Wallas. The research subjects were 2 introverted students and 2 class VIII extroverted students of SMP Negeri 3 Salatiga with high mathematical abilities. The main instrument is the researchers. Auxiliary instruments in the form of test questions, interview guidelines, and documentation. The results of the study show that at the preparation stage the extrovert subject is more confident in asking friends about things that are less understood, reading questions in the heart, while extrovert subjects always ask the researcher and read the questions out loud. At the incubation stage, introverted subjects do not do much physical activity, only take a moment to reflect and remain silent while the subject of extroverts shows physical activity. The stages of illumination of an introvert and extrovert subjects are both developing ideas in a previous way. In the verification phase, the introverted subject is more thorough than the extrovert subject but both have various ways. In general, students with extrovert and introvert personality types have fulfilled all stages of Wallas's creative thinking process.

Keywords: Extrovert, Introvert, Creative thinking process, Wallas Stages.
\end{abstract}




\section{Pendahuluan}

Berpikir kreatif merupakan salah satu kemampuan yang harus dikembangkan melalui pendidikan di sekolah, salah satunya dalam pembelajaran matematika. Hal ini sesuai dengan tujuan pembelajaran matematika, agar peserta didik memiliki kemampuan berpikir logis, analitis, sistematis, kritis, dan kreatif, serta kemampuan bekerjasama (Kemendikbud, 2006). Kemampuan berpikir kreatif dalam matematika diperlukan untuk mendayagunakan pemikiran kreatif siswa yang bertujuan membangkitkan minat siswa dan memberi keleluasaan siswa dalam membuat pilihan, mengajukan pertanyaan dan memecahkan masalah yang bermakna.

Kemampuan berpikir kreatif dalam pembelajaran matematika telah menjadi perhatian. Terdapat pada permendiknas No. 22 tahun 2006, dimana salah satu diantara tujuan yang lain, matematika merupakan suatu alat yang mampu mengembangkan cara berpikir dan membentuk pola berpikir kreatif dalam pemecahan masalah. Kreativitas sering di abaikan oleh guru (Budhi \& Kartasasmita, 2015), salah satunya dalam pemecahan masalah pembelajaran matematika. Guru sering menggunakan metode formal dan skematik bahkan orang seringkali menganggap bahwa mempelajari matematika adalah mempelajari rumus yang ada, kemudian memberikan contoh soal bagaimana rumus itu dipakai (Budhi \& Kartasasmita, 2015). Hal ini mengakibatkan siswa tidak memiliki cara pemecahan masalah yang luas sesuai dengan kemampuan berpikir kreatif mereka. Sesuai tujuan pembelajaran matematika, sudah seharusnya guru mengembangkan kemampuan berpikir kreatif siswa dalam memecahkan masalah.

Sebagai pendidik, perlu menyadari betapa pentingnya perbedaan cara berpikir setiap peserta didik salah satunya dalam proses berpikir kreatif. Akbar dan Tsoraya (2013) menyatakan dengan mengembangkan kemampuan berpikir kreatif, siswa akan mampu menyelesaikan masalah matematika dengan berbagai macam cara sesuai dengan proses berpikirnya. Oleh karena itu, kemampuan proses berpikir kreatif ini penting dimiliki oleh siswa (Fitriani \& Yarmayani, 2018; Muhtadi \& Sukirwan, 2017; Tarlina \& Afriansyah, 2016).

Untuk mengetahui proses berpikir kreatif siswa, pedoman yang dikembangkan oleh Wallas, yang menyatakan proses kreatif meliputi empat tahap yaitu: 1) persiapan, tahapan pemecahan masalah dengan mengumpulkan data, mencari pendekatan dan penyelesaiannya; 2) inkubasi, merupakan awal proses timbulnya inspirasi dan penemuan yang baru; 3) iluminasi, dimana seseorang mendapatkan sebuah masalah dari ide dan gagasan baru; 4) verifikasi, seseorang menguji dan memeriksa pemecahan masalah.

Berdasarkan penelitian yang relevan oleh Sari, Ikhsan, dan Saminan (2017) dinyatakan bahwa proses berpikir kreatif Mosharafa: JumalPendidikan Matematika Volume 8, Nomor 2, Mei 2019 Copyright $\odot 2019$ Mosharafa: Jurnal Pendidikan Matematika 
siswa dalam hal kemampuan matematika siswa memenuhi seluruh empat tahapan Wallas dengan hasil tiap indikator yang berbeda. Adapun penelitian yang dilakukan oleh Arini (2016) menyatakan bahwa siswa extrovert maupun introvert mampu mengolah informasi, namun siswa extrovert belum mampu mengketerkaitkan informasi yang ada. Subjek introvert lebih berhati-hati dan teliti di bandingkan siswa extrovert karena siswa extrovert memiliki hasil perhitungan dan hasil yang salah. G.C Jung menyatakan (Suryabrata, 1983) secara umum orang extrovert cenderung memiliki kepribadian yang aktif, bekerja cepat tetapi tidak teliti, lebih senang bekerja kelompok dan memiliki intelegensi yang relatif rendah. Orang yang introvert memperlihatkan kecenderungan sebagai seorang pendiam, mudah tersinggung, lebih suka bekerja sendirian, tidak mudah bergaul, dan memiliki intelegensi yang relatif tinggi. Berdasarkan penelitian yang relevan, peneliti ingin mengetahui bagaimana proses berpikir kreatif siswa extrovert dan introvert berdasarkan tahapan Wallas yang belum pernah diteliti oleh peneliti lain.

Sangat penting bagi peran pendidik memahami tipe kepribadian peserta didik. Sebagai indikator kunci adalah bahwa pendidik mampu mengevaluasi kinerja siswa serta mampu merancang pembelajaran yang selaras dengan perkembangan sosial, kognitif dan emosional siswa (Padmomartono, 2013). Wawasan pendidik tentang kepribadian siswa juga berguna untuk memahami motivasi yang dimiliki masing-masing siswa.

Berdasarkan latar belakang yang telah diuraikan, penelitian ini bertujuan untuk mendeskripsikan proses berpikir kreatif siswa extrovert dan introvert SMP kelas VIII berdasarkan tahapan Wallas dalam memecahkan soal matematika.

\section{Metode}

Jenis penelitian yang digunakan ialah penelitian kualitatif deskriptif. Penelitian ini medeskripsikan mengenai proses berpikir kreatif dalam menyelesaikan soal bagi siswa SMP kelas VIII berkemampuan matematika tinggi berdasarkan tipe kepribadian G.C Jung.

Penentuan subjek peneltian diambil berdasarkan kriteria tertentu sehingga penelitian ini menggunakan teknik purposive sampling. Subjek dalam penelitian ini adalah 4 siswa SMP Negeri 3 Salatiga kelas VIII yang telah mendapatkan materi mengenai pola, memiliki kemampuan tinggi dengan mempertimbangan nilai matematika dari hasil Penilaian Tengah Semester (PTS) I Tahun Pelajaran 2018/2019, dan sesuai dengan kriteria yang telah ditentukan yaitu memiliki tipe kepribadian extrovert dan introvert. Penentuan tipe kepribadian subjek dalam penelitian ini menggunakan kuesioner tipe kepribadian extrovert dan introvert.

Pada penelitian kualitatif yang menjadi instrumen utamanya merupakan peneliti itu sendiri dan menggunakan instrumen

\section{Mosharafa: Jumal Pendidikan Matematika}


pendukung berupa soal tes tertulis, lembar pedoman wawancara beserta dokumentasi. Data penelitian berupa hasil tes, hasil wawancara dan hasil dokumentasi. Hasil tes siswa digunakan untuk dijadikan sebagai bahan wawancara siswa. Hasil dokumentasi digunakan untuk menganalisis data kualitatif berupa gambar, ekspresi subjek dan kata-kata secara lisan maupun tulisan. Data penelitian berupa hasil tes, wawancara dan dokumentasi dianalisis berdasarkan 4 tahap proses berpikir kreatif Wallas yaitu: 1) tahap persiapan; 2) tahap inkubasi; 3) tahap iluminasi; 4) tahap verifikasi.

Proses analisis data dilakukan dengan cara: 1) Datar Reduction; 2) Data Display dan 3) Verification. Data reduksi dalam penelitian ini merupakan proses pemilihan data pokok, disajikan dalam bentuk yang singkat seperti grafik, flowchart dan sejenisnya kemudian dilakukan penarikan kesimpulan. Pengujian keabsahan data yang dilakukan dalam penelitian ini adalah triangulasi. Triangulasi merupakan pengecekan data dari berbagai sumber dengan berbagai cara dan waktu. Triangulasi yang digunakan adalah triangulasi waktu. Dalam rangka pengujian kreadibilitas data, maka dapat dilakukan pengulangan tes beserta wawancara dengan waktu dan situasi yang berbeda hingga mendapatkan data yang konsisten.

\section{Hasil dan Pembahasan}

Berdasarkan hasil penilaian tengah semester dan dilakukan tes tipe kepribadian extrovert dan introvert di kelas 218
VIII D sejumlah 32 siswa, didapatkan 4 subjek yang masuk dalam kriteria pengambilan subjek yaitu MDH, MIA, RAT dan SEP. Adapun data dari keempat subjek tersebut memiliki kemampuan matematika tinggi, dua subjek memiliki tipe kepribadian introvert dan dua subjek lain memilliki tipe kepribadian extrovert (lihat tabel 1).

\section{A. Proses Berpikir Kreatif Siswa Introvert Berkemampuan Tinggi}

Proses berpikir kreatif siswa berkemampuan tinggi yang memiliki tipe kepribadian introvert dengan subjek MDH dapat dilihat pada gambar 1, dalam menyelesaikan soal mengenai pola bilangan telah memenuhi semua tahap proses berpikir kreatif. Proses berpikir kreatif subjek introvert dilakukan berdasarkan tahapan proses berpikir kreatif yang terdiri dari 4 tahap, yaitu: 1) tahap persiapan; 2) tahap inkubasi; 3) tahap iluminasi; 4) tahap verifikasi.

Pada tahap persiapan, dalam memahami soal subjek perlu membaca soal berulang kali didalam hati, bertanya kepada teman mengenai hal yang kurang dipahami dan mengingat-ingat materi yang sudah diajarkan oleh guru. Pada

Tabel 1. Nama Subjek Penelitian

\begin{tabular}{lccc|}
\hline Inisial & Kategori & Nilai PTS & $\begin{array}{c}\text { Tipe } \\
\text { kepribadian }\end{array}$ \\
\hline MDH & Tinggi & 93 & Introvert \\
\hline MIA & Tinggi & 95 & Introvert \\
\hline RAT & Tinggi & 93 & Extrovert \\
\hline SEP & Tinggi & 95 & Extrovert \\
\hline
\end{tabular}

Mosharafa: Jumal Pendidikan Matematika Volume 8, Nomor 2, Mei 2019 Copyright @ 2019 Mosharafa: Jurnal Pendidikan Matematika 
tahap inkubasi subjek $\mathrm{MDH}$ mencari inspirasi dengan berhenti sejenak menutup soal yang dikerjakannya dan merenung untuk memunculkan ide, membaca soal berulang-ulang dan memikirkan cara yang akan digunakan.

Pada tahap iluminasi masing-masing soal siswa memiliki 2 cara yang berbeda.
Dapat dilihat pada gambar 1 subjek menyelesaikan soal dengan mengambil informasi yang ada pada soal kemudian mencari solusi penyelesaian dengan menghitung satu persatu jumlah kursi dari deret pertama hingga deret kesembilan kemudian mencari jumlah meja. Gambar 2 menunjukkan subjek mencoba

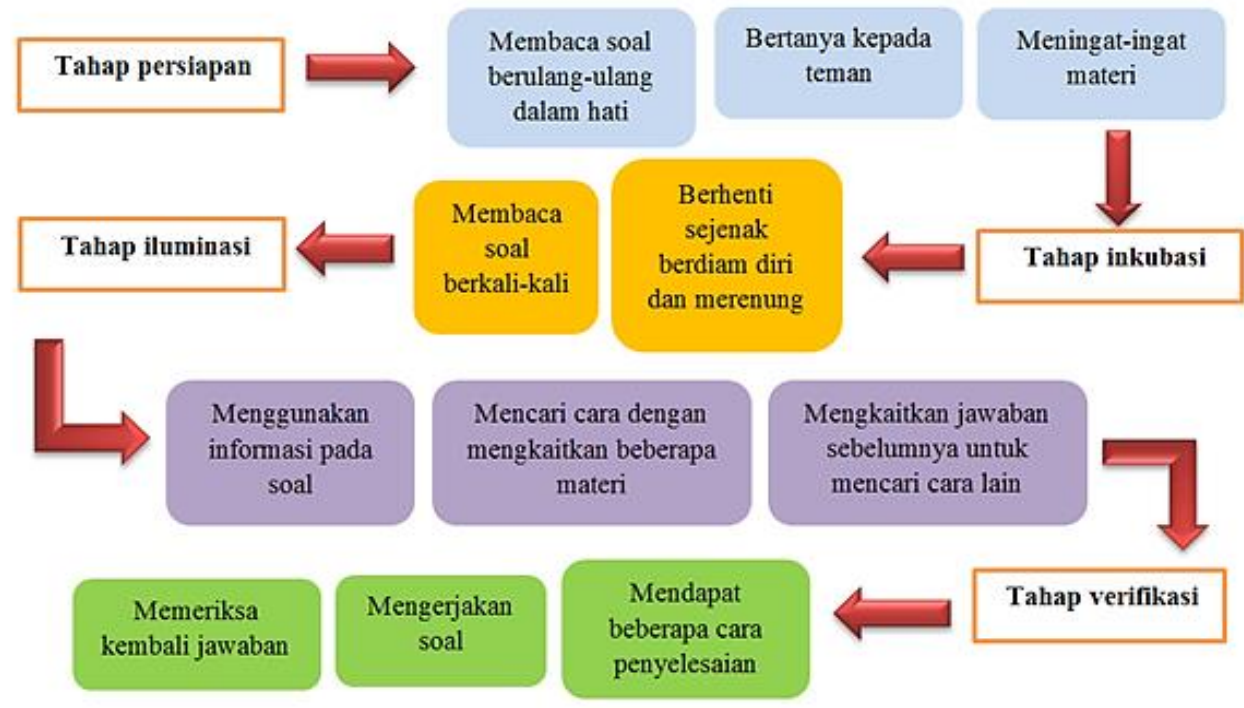

Gambar 1. Proses Berpikir Kreatif Subjek MDH

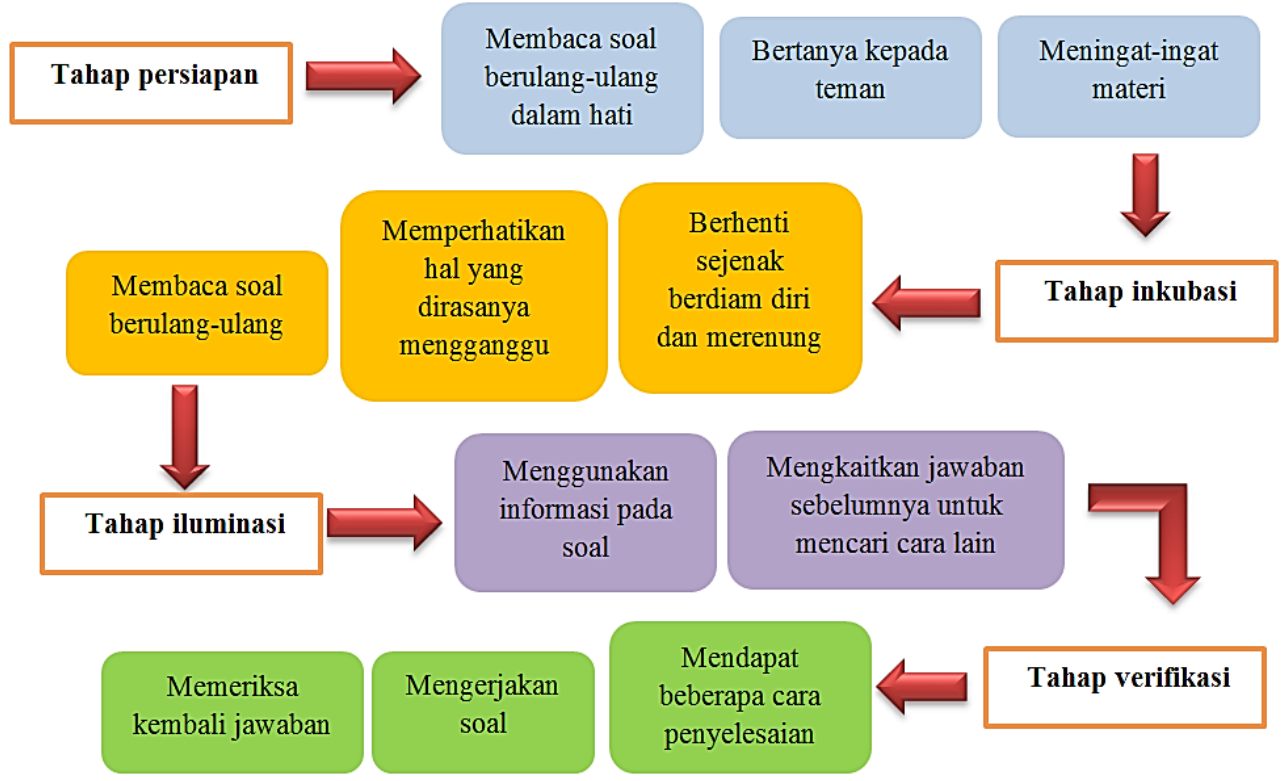

Gambar 2. Proses Berpikir Kreatif Subjek MIA 
mengkaitkan cara pertama yang sudah dikerjakannya untuk menentukan cara yang lain yaitu dengan mengkaitkan materi barisan.

Pada tahap verifikasi subjek $\mathrm{MDH}$ memikirkan solusi penyelesaian yang lain sehingga subjek memiliki lebih dari satu cara disetiap soal, terlihat bahwa cara penyelesaian kedua masih saling berkaitan dengan cara-cara sebelumnya. Subjek menyelesaikan semua soal kemudian memeriksa kembali jawaban yang telah dikerjakannya. Pekerjaan subjek diteliti oleh peneliti dan semua jawaban benar.

Berdasarkan gambar 2, proses berpikir kreatif siswa dengan tipe kepribadian introvert dengan kemampuan tinggi telah memenuhi semua tahap proses berpikir kreatif bedasarkan tahapan Wallas yang terdiri dari 4 tahap, yaitu: 1) tahap persiapan; 2) tahap inkubasi; 3) tahap iluminasi; 4) tahap verifikasi.

Pada tahap persiapan, subjek mempersiapkan diri dengan membaca soal berulang kali, mengingat-ingat materi yang sudah pernah diajarkan, dan bertanya kepada teman mengenai hal yang tidak ia pahami. Pada tahap inkubasi, subjek cenderung berdiam diri dengan mengamati keadaan sekitar dan sesekali membaca soal untuk menemukan ide.

Pada tahap iluminasi subjek MIA memiliki 2 cara penyelesaian pada masingmasing soal. Cara pertama yaitu dengan menghitung satu-persatu jumlah meja beserta kursi pada deret keenam dan kesembilan kemudian mengembangkan cara lain dengan mengkaitkannya dengan materi barisan.

Pada tahap verifikasi, siswa mampu mengerjakan semua soal, dan mampu menemukan beberapa cara lain yang berkaitan dengan cara pertama dalam menyelesaikan soal. Subjek MIA memeriksa kembali hasil pekerjaannya dan jawaban yang dikerjakan kemudian diteliti

Tabel 2.

Hasil Data Valid Subjek Introvert

\begin{tabular}{|c|c|c|}
\hline $\begin{array}{c}\text { Tahap Proses Berpikir Kreatif } \\
\text { Wallas }\end{array}$ & & Indikator Tahap Proses Berpikir Kreatif Subjek Introvert \\
\hline Tahap persiapan & 1) & $\begin{array}{l}\text { Siswa membaca soal dalam hati } \\
\text { Siswa mampu memahami soal dengan membaca soal } \\
\text { berulang kali } \\
\text { Mengingat-ingat materi yang sudah diajarkan sebelumnya } \\
\text { Siswa cenderung bertanya dengan temannya dibanding } \\
\text { dengan peneliti }\end{array}$ \\
\hline Tahap inkubasi & 1) & $\begin{array}{l}\text { Siswa cenderung terdiam untuk memunculkan ide } \\
\text { Melakukan aktivitas merenung dan tidak beranjak dari } \\
\text { tempat duduk }\end{array}$ \\
\hline Tahap iluminasi & 1) & $\begin{array}{l}\text { Siswa mengidentifikasi informasi yang ada pada soal } \\
\text { Siswa menetapkan langkah penyelesaian } \\
\text { Siswa dapat mengembangkan idenya dari cara sebelumnya }\end{array}$ \\
\hline Tahap verifikasi & $\begin{array}{l}\text { 1) } \\
\text { 2) } \\
\text { 3) }\end{array}$ & $\begin{array}{l}\text { Siswa mengamati dan memeriksa kembali jawabannya } \\
\text { Memiliki beberapa cara dalam menyelesaikan soal } \\
\text { Siswa menjawab seluruh soal dengan benar }\end{array}$ \\
\hline
\end{tabular}


oleh peneliti dan semua jawaban benar. Sehingga diperoleh data proses berpikir kreatif siswa introvert, sebagai data yang valid (lihat tabel 2).

\section{B. Proses Berpikir Kreatif Siswa Extrovert Berkemampuan Tinggi}

Berdasarkan gambar 3 dapat diketahui subjek RAT telah memenuhi 4 tahapan proses berpikir kreatif siswa berdasarkan teori Wallas yang terdiri dari 4 tahap, yaitu: 1) tahap persiapan; 2) tahap inkubasi; 3) tahap iluminasi; 4) tahap verifikasi.

Pada tahap persiapan siswa lebih dulu membaca seluruh soal yang ada, beberapa kali bertanya kepada peneliti mengenai hal yang kurang dipahami.

Pada tahap inkubasi siswa membaca soal berulang kali dengan bersuara, diam sejenak dengan menyenderkan bahu dikursi, berdiri sambil membaca soal, mengkaitkaan soal dengan materi lain yang diajarkan oleh guru.

Pada tahap iluminasi subjek RAT memiliki 3 cara dalam menjawab soal nomor satu dan memiliki 2 cara untuk menyelesaikan soal nomor dua. Subjek menggunakan informasi pada soal dengan menghitung jumlah kursi dari baris pertama hingga baris keenam, kemudian menentukan caranya sendiri yaitu dengan menghitung kursi terlebih dahulu kemudian menentukan jumlah meja.

Pada tahap verifikasi subjek RAT sudah melakukan pengecekan kembali namun la tidak menyadari ada satu cara yang salah namun memiliki jawaban yang benar.

Berdasarkan gambar 4 subjek SAP telah memenuhi seluruh tahapan proses berpikir kreatif berdasarkan teori Wallas yang terdiri dari 4 tahap, yaitu: 1) tahap

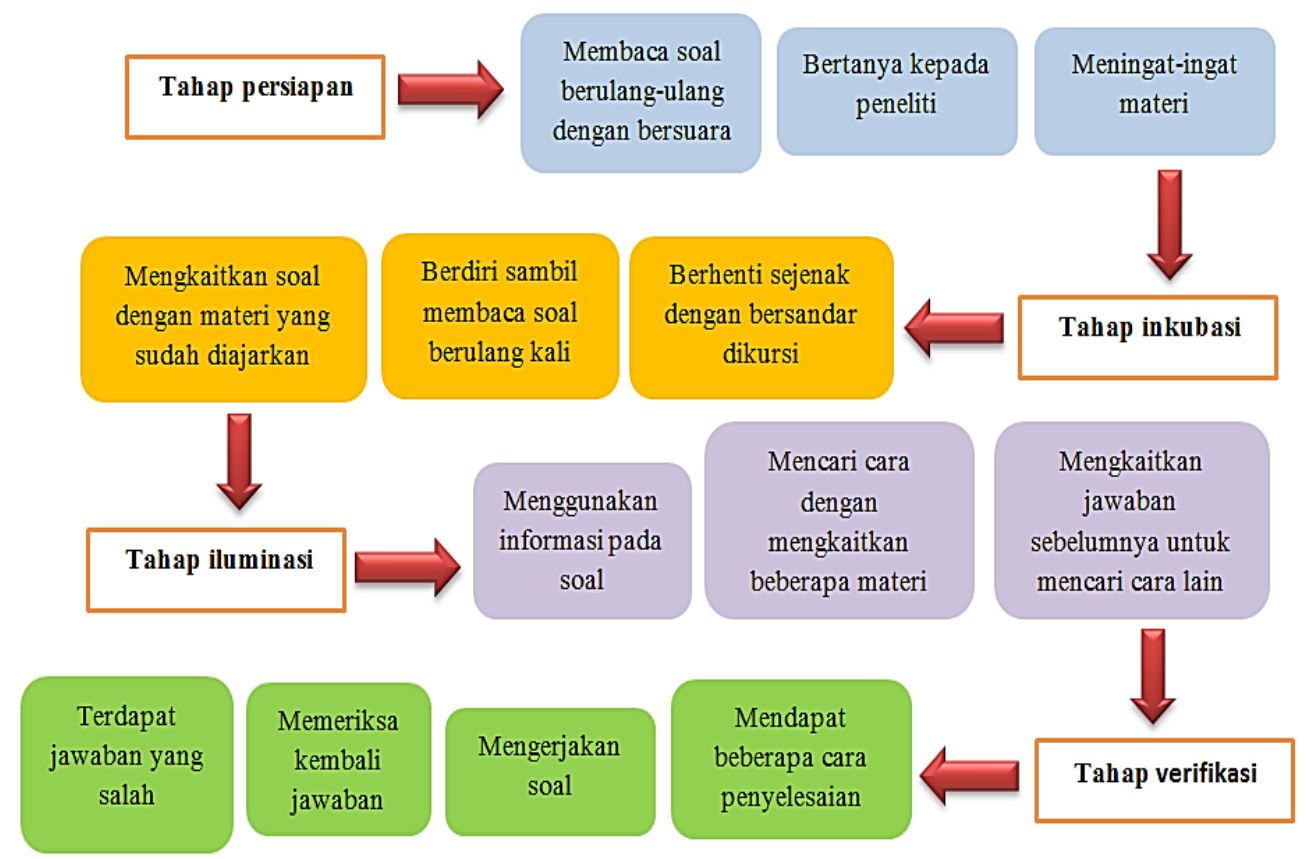

Gambar 3. Proses Berpikir Kreatif Subjek RAT 
persiapan; 2) tahap inkubasi; 3) tahap iluminasi; 4) tahap verifikasi.

Pada tahap persiapan dalam memahami soal siswa mengingat-ingat materi yang sudah diajarkan di awal semester lalu, siswa beberapakali bertanya kepada peneliti mengenai hal yang kurang dipahami. Pada tahap inkubasi siswa mencari inspirasi dengan melakukan aktivitas seperti diam sejenak dengan merenung sambil menggerak-gerakan kaki, bersandar dikursi dan membaca soal berulang kali dengan mengangkat soal dari meja.

Pada tahap iluminasi subjek mampu menyelesaikan masing-masing soal dengan 2 cara. Subjek menggunakan informasi pada soal kemudian menghitung meja dan kursi satu persatu dari baris pertama hingga baris ke lima belas kemudian subjek menghitung jumlah kursi beserta meja pada deret keenam dan deret kesembilan. Kemudian setelah cara pertama didapatkan subjek mencoba-coba mencari dengan cara lain.

Pada tahap verifikasi siswa menemukan cara dan ide yang kemudian melakukan penyelesaian pada soal yang ada, setelah dicek oleh peneliti subjek SAP mengerjakan soal dengan benar dan memiliki beberapa cara penyelesaian namun tidak melakukan pengecekan kembali.

Dari hasil deskripsi di atas, maka diperoleh data proses berpikir kreatif siswa extrovert, sebagai data yang valid (lihat tabel 3).

Berdasarkan deskripsi hasil penelitian yang didasarkan pada tahapan Wallas, yaitu tahap persiapan, tahap inkubasi, tahap iluminasi dan tahap verifikasi, maka di dapatkan data proses berpikir kreatif

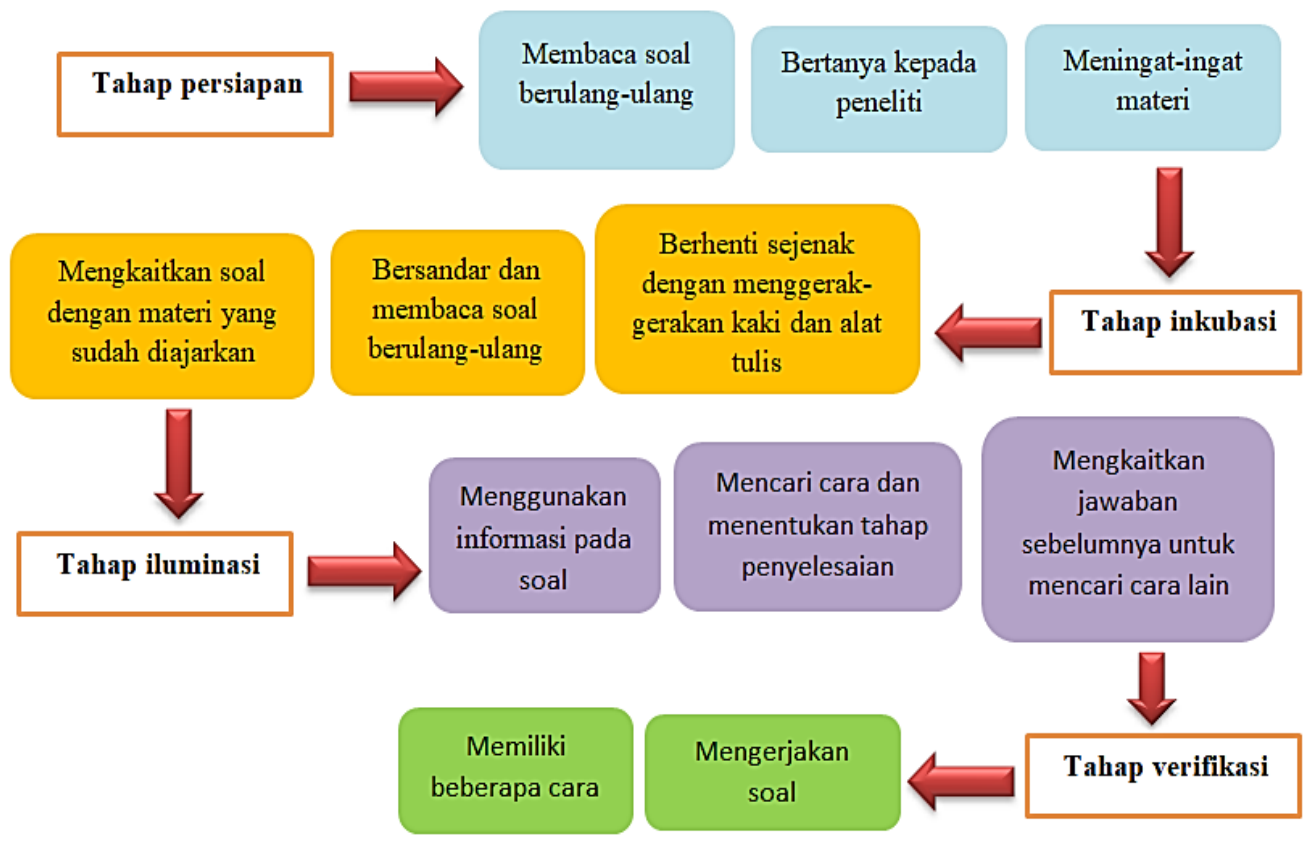

Gambar 4. Proses Berpikir Kreatif Subjek SAP 
siswa berkemampuan tinggi telah atau beranjak dari tempat duduk. Pada

memenuhi semua tahapan, hal ini sejalan dengan penelitian Paramitha (2017); Sari, Ikhsan, dan Saminan, (2017); Sari (2016); Arifin \& Bharata (2017). Berikut merupakan data proses berpikir kreatif dengan tipe kepribadian introvert dan extrovert:

\section{Siswa Introvert}

Pada tahap persiapan, untuk menyelesaikan soal siswa mengawali dengan membaca soal dalam hati, selanjutnya siswa mengamati petunjuk dan informasi pada soal dengan cermat serta mengingat-ingat kembali mengenai materi yang berkaitan dengan soal dan untuk hal yang belum dipahami siswa introvert cenderung bertanya kepada teman dibanding dengan peneliti. Pada tahap inkubasi siswa introvert cenderung diam, tenang dan merenung untuk memunculkan idenya, dan tidak banyak aktivitas fisik yang dilakukan seperti berdiri tahap iluminasi, siswa mendapatkan ide pemecahan masalah diawali dengan mengidentifikasi informasi yang ada pada soal. Selanjutnya siswa menuliskan cara penyelesaian soal dan siswa mengembangkan idenya dari cara sebelumnya. Pada tahap verifikasi siswa introvert memiliki beberapa cara penyelesaian, memeriksa beserta mengamati kembali jawaban yang telah dikerjakan dan memiliki jawaban yang benar. Hal ini sesuai dengan penelitian yang dilakukan Arini (2016); Qomariah (2016) yang menyatakan bahwa ketika siswa introvert mengecek kembali langkahlangkah yang telah dilakukan karena siswa introvert cenderung berhati-hati dalam mengambil keputusan.

\section{Siswa Extrovert}

Pada tahap persiapan, dalam merespon soal diawali dengan membaca soal dengan bersuara, siswa mampu memahami

Tabel 3.

Hasil Data Valid Subjek Extrovert

\begin{tabular}{cll}
\hline Tahap Proses Berpikir Kreatif Wallas & & Indikator Tahap Proses Berpikir Kreatif Subjek Extrovert \\
\hline Tahap persiapan & 1) & Siswa membaca soal sedikit bersuara \\
& 2) & Siswa mampu memahami soal dengan membaca soal \\
& berulang kali & \\
& 3) & Mengingat-ingat materi yang sudah diajarkan sebelumnya \\
& 4) & Siswa cenderung bertanya dengan peneliti langsung \\
\hline Tahap inkubasi & 1) & Siswa cenderung terdiam untuk memunculkan ide \\
& 2) & Melakukan aktivitas kecil untuk memunculkan ide \\
& 3) & Beranjak dari tempat duduk \\
\hline Tahap iluminasi & 1) & Siswa mengidentifikasi informasi yang ada pada soal \\
& 2) & Siswa menetapkan langkah penyelesaian \\
& 3) Siswa dapat mengembangkan idenya dari cara & \\
\hline Tahap verifikasi & 1) & Siswa cenderung kurang teliti dan terburu-buru \\
& 2) & Memiliki beberapa cara dalam menyelesaikan soal \\
\hline
\end{tabular}


maksud dari soal dengan membaca soal berulang kali, siswa extrovert cenderung memilih untuk bertanya kepada peneliti mengenai hal yang kurang dipahami. Hal ini sesuai dengan penelitian Dominika dan Virlia (2018) yang menyatkan siswa extrovert lebih mudah menyampaikan setiap emosi yang dirasakannya dengan menjalin komunikasi dengan orang-orang disekitarnya. Pada tahap inkubasi cenderung melakukan aktivitas kecil untuk memunculkan idenya. Pada tahap iluminasi siswa mengidentifikasi informasi yang ada pada soal lalu menentukan cara yang digunakan kemudian menetapkan langkah penyelesaian, dari cara pertama yang digunakannya siswa mampu mengembangkan idenya. Pada tahap verifikasi siswa cenderung kurang teliti namun memiliki beberapa cara dalam menyelesaikan soal. Hal ini sesuai dengan penelitian yang dilakukan oleh Arini (2016) bahwa siswa extrovert kurang teliti dalam menyelesaikan soal yang diberikan selain itu berdasarkan penelitian yang dilakukan Febriani dan Ratu (2018), siswa berkemampuan tinggi mampu mengerjakan soal dengan baik memenuhi semua tahapan proses berpikir kreatif walaupun masih terdapat kesalahan.

\section{Penutup}

Berdasarkan hasil dan pembahasan tersebut, maka dapat disimpulkan bahwa pada tahap persiapan, siswa extrovert dan introvert mampu memahami soal dengan membaca soal berulang, namun siswa extrovert lebih percaya diri di banding siswa introvert. Pada tahap inkubasi siswa introvert memunculkan ide dengan terdiam, dan tidak beranjak dari tempat duduk berbeda dengan siswa extrovert dalam memunculkan ide dengan melakukan aktiftas kecil dengan bersandar berdiri, menggerak-gerakan kaki dan menyusun cara. Pada tahap iluminasi siswa introvert maupun extrovert tidak memiliki perbedaan yang signifikan dimana keduanya mengidentifikasi informasi yang ada pada soal untuk menentukan cara yang akan digunakan, kemudian menentukan tahap penyelesaian dan mengembangkan idenya dari jawaban sebelumnya. Pada Tahap Verifikasi subjek introvert lebih teliti dibandingkan subjek extrovert. Adapun subjek introvert mengamati serta memeriksa kembali jawaban yang sudah dikerjakan, subjek memiliki jawaban yang benar, memiliki beberapa cara penyelesaian sedangkan subjek extrovert masih terdapat jawaban yang belum tepat, dimana salah satu siswa juga tidak melakukan pengecekan kembali namun subjek introvert mapun extrovert memiliki bebrapa cara penyelesaian.

\section{UCAPAN TERIMA KasIH}

Penulis mengucapkan terimakasih kepada semua pihak yang telah berpartisipasi dalam pelakasanaan penelitian ini terutama kepada Kepala Sekolah dan siswa di SMP Negeri 3 Salatiga. 


\section{DAfTAR PUStaka}

Akbar, R. O., \& Tsoraya, R. (2013). Pengaruh Kemampuan Berpikir Statistik Terhadap Kreativitas Berpikir Siswa dalam Matematika (Studi Kasus di Kelas XI IPA MAN 2 Kota Cirebon ). Eduma.

https://doi.org/http://dx.doi.org/10.2 4235/eduma.v2i2.40.g40

Arifin, M., \& Bharata, H. (2017). Proses Berpikir Kreatif Matematis Siswa Ditinjau Dari Pengetahuan Awal Tinggi Dan Perspektif Gender. Posiding Seminar Nasional Matematika Dan Pendidikan Matematika 2017, 1, 175-184.

Arini, Z., \& A. H. R. (2016). Profil Kemampuan Penalaran Siswa SMP dalam Menyelesaikan Masalah Matematika Ditinjau dari Tipe Kepribadian Extrovert dan Introvert. MATHE Dunesa, 2(5), 127-136.

Budhi, W. S., \& Kartasasmita, B. G. (2015). Berpikir Matematis Matematika untuk Semua, 1.

Dominika, \& Virlia, S. (2018). Hubungan Tipe Kepribadian Ekstrovert-Introvert dengan Penerimaan Sosial Pada Siswa. KONSELOR, 7(1), 31-39. https://doi.org/10.24036/020187187 35-0-00

Fitriani, S., \& Yarmayani, A. (2018). Pengembangan Rubrik Berpikir Kreatif Siswa Menengah Atas dalam Menyelesaikan Masalah Matematika. Mosharafa: Jurnal Pendidikan Matematika, 7(1), 33-38.

Kemendikbud. (2006). Peraturan Menteri Pendidikan Nasional Republik Indonesia Nomor 22 Tahun 2006 tentang, 105.

Muhtadi, D., \& Sukirwan. (2017). Implementasi Pendidikan Matematika
Realistik (PMR) untuk Meningkatkan Kemampuan Berpikir Kreatif Matematik dan Kemandirian Belajar Peserta Didik. Mosharafa: Jurnal Pendidikan Matematika, 6(1), 1-12.

Padmomartono, S., \& W. (2013). Teori Kepribadian. Salatiga: Griya Media.

Paramitha, N. T. N. H. Y. (2017). Analisis Proses Berpikir Kreatif dalam Memecahkan Masalah Matematika Materi Aritmatika Sosial Siswa SMP Berkemampuan Tinggi. Jurnal Miitra Pendidikan (JMP Online), 1, 983-994.

Qomariah, N. (2016). Kuadrat ditinjau dari Perbedaan Kepribadian Extrovert dan Introvert. Apotema: Jurnal Program Studi Pendidikan Matematika, 2, 8795.

Sari, A. P., Ikhsan, M., \& Saminan, S. (2017). Proses Berpikir Kreatif Siswa dalam Memecahkan Masalah Matematika Berdasarkan Model Wallas. Beta Jurnal Tadris Matematika, $\quad 10(1), \quad 18$. https://doi.org/10.20414/betajtm.v1 $0 i 1.102$

Sari, L. N. (2016). Proses Berpikir Kreatif Siswa SMP dalam Memecahkan Masalah Matematika Berdasarkan Adversity Quotient (AQ). Kreano, 7(2), 163-170.

Febriani, S., \& Ratu, N. (2018). Profil Proses Berpikir Kreatif Matematis Siswa dalam Pemecahan Masalah Open-Ended Berdasarkan Teori Wallas. Mosharafa: Jurnal Pendidikan Matematika, 7, 251-262.

Suryabrata, S. (1983). Teori Belajar dan Pembelajaran di Sekolah Dasar. Jakarta: PT. Elex Media.

Tarlina, W. H., \& Afriansyah, E. A. (2016). Kemampuan Berpikir Kreatif Siswa Melalui Creative Problem Solving. 
EduMa, 5(2), 42-51.

\section{Riwayat Hidup Penulis}

\section{Nanda Sriretno Pangestu, S.Pd.}

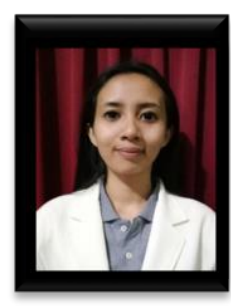

Lahir di Kabupaten Semarang 5 Juni 1997. Studi S1 Pendidikan Matematika Universitas Kristen Satya Wacana.

\section{Tri Nova Hasti Yunianta, M.Pd.}

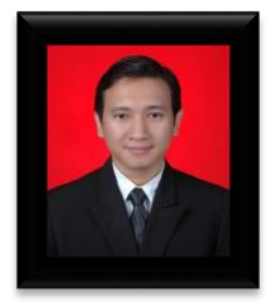

Lahir di Pati, 20 Juni 1987.

Tahun 2009 memperoleh

gelar S1 Pendidikan

Matematika di Universitas

Negeri Semarang dan kemudian melanjutkan kuliah S2 Pendidikan Matematika di Universitas

Negeri Semarang pada tahun 2010 dan menyelesaikannya pada tahun 2012. Mengajar di UKSW Salatiga sejak tahun 2012. Pernah mengikuti Pelatihan Pembelajaran Kontekstual SMP/MTs untuk dosen LPTKS tahun 2013, mengikuti Training of Pedagogy Lecturers in Teacher Training Curricula and Material tahun 2014, dan mengikuti pelatihan tentang Buku Sumber untuk Dosen LPTK: Pembelajaran Literasi SD/MI dan SMP/MTs, IPA SD/MI, Matematika SD/MI tahun 2015 kerjasama dengan USAID (Amerika Serikat) dan Pemerintah Indonesia. Pernah mengikuti Pelatihan Building Pedagogical and Content Knowledge in Teacher Educators, di The University of The Sunshine Coast, Queensland, Australia tahun 2015. 